\title{
IMPROVING PRODUCTION OF SOFT-SHELLED SWIMMING CRABS: MACROSCOPIC SIGNS OF MOLTING AS A TOOL FOR SELECTION AND MANAGEMENT OF Callinectes danae AND Callinectes exasperatus (PORTUNIDAE, DECAPODA, CRUSTACEA)
}

\section{[Aprimoramento na produção de siris de casca mole: sinais macroscópicos de muda como uma ferramenta para a seleção e gestão de Callinectes danae e Callinectes exasperatus (Portunidae, Decapoda, Crustacea)]}

\author{
Antonio Ostrensky, Robson Ventura, Angélica Maria Araújo Corrêa, Gislaine Vieira \\ Santos, Gisela Geraldine Castilho-Westphal \\ *Correspondência: ostrensky@ufpr.br
}

\begin{abstract}
In order to improve the efficiency of soft-shell crab production, we investigated whether it is technically viable to increase harvesting rates of soft-shelled crabs of the species Callinectes danae and $\mathrm{C}$. exasperatus by selecting animals based on macroscopic molt signs and maintaining them in specific facilities. The study was conducted in three stages. In the first stage, macroscopic anatomic changes possibly related to the molting cycle identified under laboratory conditions. In the second stage we used the macroscopic clues observed in the first assay to select premolt animals harvested from their natural environments. Yet in this stage of the work, the relationship between the macroscopic changes and the microscopic signs of molting was evaluated. Lastly, an assay verified the technical feasibility of increasing the fraction of soft-shells in the total catch by selecting and maintaining premolt swimming crabs of species $C$. danae and $C$. exasperatus in specific facilities until the molt. Our results indicated that we can macroscopically identify, and therefore select, individuals in premolt phases II, III and IV that will soon molt, but further investigations are necessary to identify the requisite conditions for successful molting of individuals in premolt phase I

Key Words: fisheries; molt; soft-shell; swimming crabs
\end{abstract}




\section{INTRODUCTION}

Portunidae (Decapoda, Crustacea), commonly known as swimming crab, inhabit coastal regions (Melo, 1996) and are considered important fishery resources in many countries (FAO 2008). The most exploited swimming crab species in the world are the gazami crab, Portunus trituberculatus (Miers, 1876), the flower crab, Portunus pelagicus (Linnaeus, 1758) (India and Pacific Oceans) and the Atlantic blue crab Callinectes sapidus (M. J. Rathbun, 1896) (central, west and northwest Atlantic Ocean). The fishing of these three species generated approximately 585,000 tons in 2005, and P. trituberculatus accounted for $60 \%$ of the total catch alone (FAO 2008). Despite efforts to develop restocking and aquaculture techniques in several parts of world, exploitation directly from the natural environment is still the main method for obtaining these species (Wickins and Lee 2002).

One way of commercializing swimming crabs is in the form of softshelled crabs, i.e. crabs in the postmolt period that succeeds the molting process. Soft-shelled crabs are appreciated in international cuisines and have a high market value (Perry and Malone 1989, Wickins and Lee 2002, Meyer 2003). In countries such as Brazil, soft shelled crabs are collected from nature and there is no manipulation of them to increase the fraction of softshells in the total catch. However, softshelled crabs represent an insignificant fraction of the total production of the exploited species (Castro et al. 2005). In other regions of the world, such as in the United States of America and Mexico, aside from traditional fisheries, there is a specialized technique to increase production rates of soft-shelled blue crabs (C. sapidus). In these operations, swimming crabs captured from their natural environments are submitted to selection prior to being transferred to specific facilities. Only animals in the premolt stage are selected and maintained until the occurrence of the molting process. After molting, they will be packed, frozen, and sold on the market (Lee and Sanford 1962, Cupka and Van Engel 1979, Oesterling 1984). In the USA, 2,500 tons of soft-shelled blue crabs (C. sapidus) were produced using this technique in the year 2000 (Blue Crab Technical Work Group 2005). The selection process is based on macroscopic monitoring of the molting cycle.

The molting cycle of crustaceans can be divided into five stages: A (recent postmolt), B (late postmolt), C (intermolt), $D$ (premolt) and $E$ (ecdysis). The stages, with the exception of ecdysis, can be further subdivided (Skinner 1962, Drach and Tchernigovtzeff 1967, Warner 1977). Skinner (1962) observed that the molting cycle for the blackback land crab, Gecarcinus lateralis (Gecarcinidae), varied from four to six months, and the longer part of the cycle corresponded to the intermolt period $(\mathrm{C})$ and the premolt period, which ranged from $16 \%$ to $25 \%$ of the cycle (approximately 30 days). According to Warner (1977), the premolt and intermolt stages represented $67 \%$ and $20 \%$ of the molting cycle duration in brachyuran crustaceans, respectively. Freeman et al. (1987) observed an average time of the molting cycle of 37 days for $\mathrm{C}$. sapidus, and the crab was in the intermolt stage $67.5 \%$ of the time, while it was in the premolt stage between $21 \%$ and $35 \%$ of the time ( 8 to 13 days). The duration of the molting cycle varied according to the species and was directly proportional to the size of the animal (Warner 1977, Freeman et al. 1987).

According to Drach and Tchernigovtzeff (1967), the premolt stage can be divided into five sub-stages that are characterized by changes of the exoskeleton, in the epimeral tissue and in the generation of new setae. In the 
earliest sub-stage D0, the epidermis detaches from the internal part of the cuticle due to enzymatic action, which is a process known as apolysis. In substages D1, D2, and D3, the development of pre-exuvial layers (epicuticle and exocuticle) occurs, and the epidermis invaginates to form new setae. The substages can be identified according to the level of setal development, the distance between the new and old cuticle, and the degree of reabsorption of minerals and nutrients from the old exoskeleton. In sub-stage D2, the crustacean stops eating, and the reabsorption of minerals and nutrients occurs in specific locations, such as in the area surrounding the epimeral line. In sub-stage D4, reabsorption is completed, the epimeral line disrupts in the old exoskeleton, and the absorption of marine water begins (Warner 1977).

This cycle can be easily monitored using traditional histological analyses. However, studies developed with C. sapidus (Oesterling 1984) and the arched swimming crab, Callinectes arcuatus Ordway, 1863 (Portunidae) (Wehrtmann and Mena-Castañeda 2003), showed that the molting cycle can be monitored by observing macroscopically specific anatomical alterations in the body of the animals, and this procedure substantiates the increase of the production rates of soft-shelled crabs. Fishermen exploiting other swimmingcrabs species such as the dana swimming crab, Callinectes danae (Portunidae) and the rugose swimming crab, Callinectes exasperatus (Portunidae), - abundant species in the Caribbean and South America - could improve their profits using this technique. However, such methodology has not been validated for these species. The present study investigated whether it is technically viable to increase production rates of soft-shelled crabs of the species C. danae and C. exasperatus by selecting animals based on macroscopic molt signs and their maintenance in specific facilities until the molt.

\section{MATERIAL AND METHODS}

The present study was conducted in three parts. In the first part, macroscopic anatomic changes likely related to the molting cycle were indentified under laboratory conditions. In the second part, we used the macroscopic clues observed previously to select premolt animals harvested from their natural environments. Still in this part of the work, we evaluated the relationship between the macroscopic changes and the microscopic signs of molting. Lastly, an assay verified the technical feasibility of increasing the fraction of soft-shells in the total catch by selecting and maintaining premolt swimming crabs of species $\mathrm{C}$. danae and C. exasperatus in specific facilities until the molt.

Animals were collected in the locality of Acupe (12.39'30" $S$ and $38^{\circ} 44^{\prime} 54^{\prime \prime}$ W), west of the Baía de Todos os Santos (BTS) in Bahia, Brazil. Appropriate standard fishing techniques were used to collect each species. Immediately after the swimming crabs had been captured, they were transferred to transport tanks containing saltwater and provided with aeration. Subsequently, they were transported to the laboratory where the assays were performed. The taxonomic identification followed previously published criteria from Melo (1996) and Coelho and Ramos-Porto (1992). Animals were weighed on a table scale (Bel Engineering, precision of 0.01 grams), and their carapace width (CW) was measured using calipers. The $\mathrm{CW}$ was determined as the largest distance between the tops of the lateral spines.

Identification of macroscopic signs of premolt 

tool for selection and management

Twenty specimens of C. exasperatus (ten of each sex) and nineteen specimens of $C$. danae (nine females and ten males) were used in the assays. The selected animals were of different sizes and were in different stages of intermolt. The swimming crabs were individually maintained in plastic containers with ten liters of saltwater. The water used in the experiments was collected from the BTS and was filtered with a sand filter, a $500-\mu \mathrm{m}$ bag filter, and was UV sterilized. The water was renewed 25 times per day. Environmental parameters were not controlled, thus the water temperature, total ammonia, and salinity were monitored three times per day (08:00; 12:00 and 17:00). The concentration of ammonia was determined by the use of a saltwater aquarium kit (Labcon Teste de Amônia Tóxica - água salgada). Animals were fed daily in the morning with 15 grams of a mixture of chopped fish, oysters, and commercial shrimp food at a ratio of: $53.6 \%, 17.8 \%$ and $28.6 \%$, respectively. After a period of five hours, the leftover foodstuffs were siphoned, and the experimental unit was cleaned with a plastic sponge. After the feeding procedure, the water of each container was completely replaced.

Animals were checked daily for mortality and molts. The propodus and the dactylus of the fifth pereiopod of each crab were carefully examined once a week for the identification of macroscopic signs of premolt. The examination considered the descriptions of premolt signs that were previously reported by Oesterling (1984) for the blue crab, C. sapidus, and the descriptions reported by Wehrtmann and Mena-Castañeda (2003) for $\mathrm{C}$. arcuatus. These authors have defined that the most reliable signs of pre-molt are the color changes of animals associated with the formation of the new exoskeleton and the formation of a double line in the marginal region of the pereiopods. In addition, the epimeral line was examined. The observations of these changes were recorded with a digital camera, without any magnification, during the experimental period (35 days). of premolt

Identification of microscopic signs

Animals of both species that were captured directly from their natural environments were selected according to their macroscopic signs of premolt, which were determined in the previous experiment, for the microscopic observations. The dactylus of the fifth pereiopod and the scaphognathite were checked under an optical microscope (100x magnification), and the patterns observed were compared to the phases of setal development that were previously described by Drach and Tchernigovtzeff (1967) and by Stevenson (1985).

Production of soft-shelled crabs

The assay lasted for 14 days. After the transported to the laboratory, the specimens were submitted to a resting period of 8 to 24 hours. Forty animals of each species were used, twenty of each sex (C. exasperatus: CW min. $6.09 \mathrm{~cm}$, max. $10.60 \mathrm{~cm}$; C. danae: CW min. 6.05 $\mathrm{cm}$, max. $10.80 \mathrm{~cm}$ ). In the laboratory, they were classified relative to their premolt stage according to the macroscopic characteristics that were observed in the previous stage of the present research (Table 1).

Table 1 - Premolt phase of animals used in the experimental unit of production of soft-shelled crabs from Callinectes danae and Callinectes exasperatus.

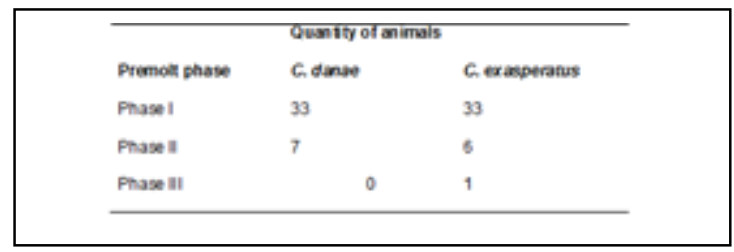


Animals of each species were distributed in eight polyethylene tanks (with an area of $0.237 \mathrm{~m} 2$ and a maximum volume of $0.1 \mathrm{~m} 3$ ) and maintained in 40 liters of salt water. The experimental density was five individuals per tank (approximately 21 individuals per m2). Each tank was equipped with an individual aeration system (compressed air) and a continuous water supply system (renewed approximately nine times every 24 hours). Environmental parameters were not controlled, thus the water temperature, total ammonia, and salinity monitoring were monitored following the same methodology and schedule used in the first assay. In this assay we also monitored the dissolved oxygen once a day $(08: 00 \mathrm{~h})$ using a digital probe.

Following the methods that were developed for other swimming crab species, the animals were not fed (Wickins and Lee 2002, Maya de la Cruz et al. 2007). Observations of the premolt stage of all animals were performed three times a day during the first eight days (00:00, 08:00 and 16:00) and once a day in the last six days. The animals were identified with a rubber ring of a distinct color for each individual. Individuals identified as being in phase III of the premolt stage were confined within a dome made of a plastic net to avoid cannibalism. After the molting process began or mortality, the animals were taken out of the tanks and were immediately replaced by another individual in the premolt phase and with a similar CW and weight. observed a change in coloration and the occurrence of a double line (a distal or exterior line and a proximal or interior line) occurred in the marginal region of the propodus and the dactylus of the fifth pereiopod, which became more evident with the approach of the ecdysis process (Fig. 1 and 2). Based on these characteristics and on the distance between the exterior and interior lines, it was possible to distinguish three phases of the premolt stage for both species.

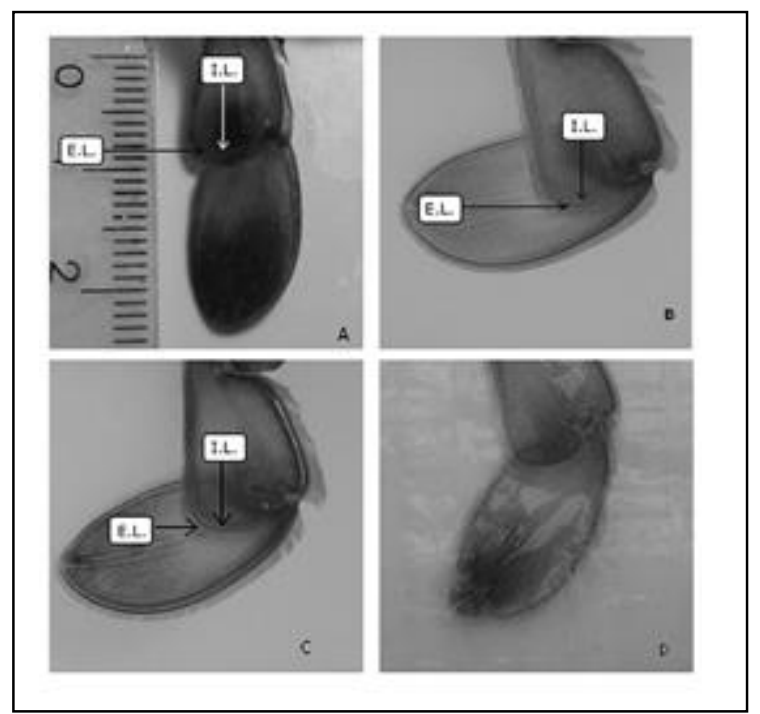

Figure 1 - Macroscopic characterization of the premolt phases in Callinectes danae. Images $A, B$ and $C$ show premolt stages I, II and III, respectively. Image D shows the pereiopod of a buster right before the molting process. $E L=$ External line (old cuticle); IL = Internal line (new cuticle).

\section{RESULTS}

\section{Identification of the macroscopic signs of premolt \\ It was possible to identify clear macroscopic characteristics of the premolt stage in both species. We}



tool for selection and management between 25 and $28^{\circ} \mathrm{C}$, and the total ammonium concentration remained under $0.12 \mathrm{mg} \cdot \mathrm{L}-1$.

Table 2 - Estimate of the time lag between each premolt phase and the occurrence of the ecdysis for Callinectes danae and Callinectes exasperatus when kept in captivity.

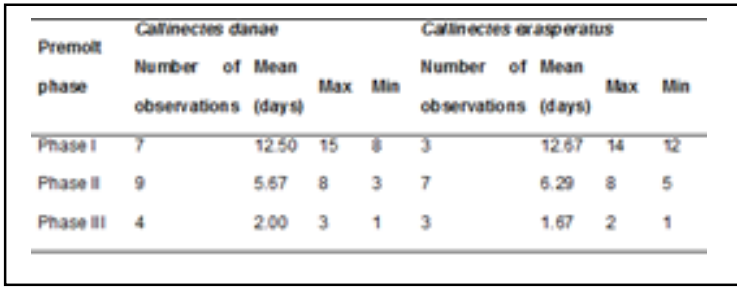

Identification of the microscopic signs of premolt

The microscopic analysis of the dactylus of the fifth pereiopod and of the scaphognathite of $\mathrm{C}$. danae and $\mathrm{C}$. exasperatus showed similar characteristics of setal development for both species. Three phases of setal development were characterized: initial, advanced, and final premolt phases, which correspond to macroscopic premolt phases I, II, and III - IV (Table 3 , Fig. 3), respectively. The process of setal development in the new tegument of the scaphognathite appeared to be more evident in the advanced and final premolt phases, compared to the fifth pereiopod dactyle. males of C. exasperatus molted. Among these, only one male reinitiated the intermolt cycle by the end of the assay (phase I of the premolt phase). Among the animals that survived and did not molt by the end of assay, four passed to the premolt phase and four remained in the intermolt phase. An estimate of the duration of the premolt phases could be determined for some individuals of both species. The phase I lasted for the longest duration, followed by the phase II and the phase III was the shortest (Table 2). The water salinity ranged from 33 to $36 \mathrm{psu}$, the water temperature varied 


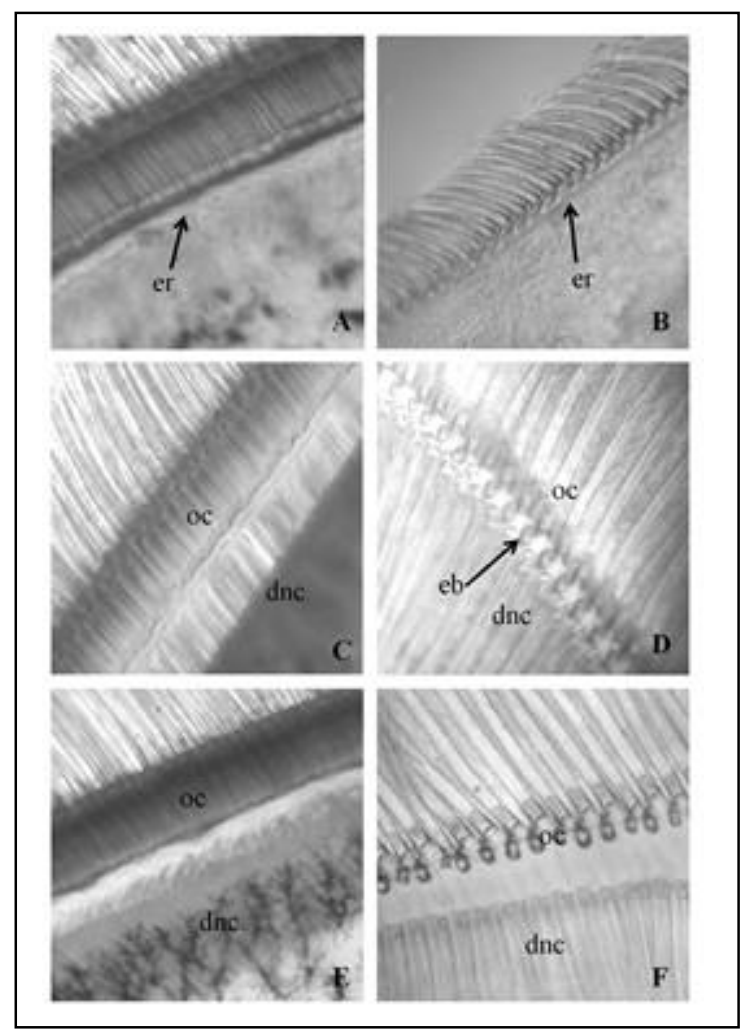

Figure 3 - Microscopic observation of the dactile and the scaphognathite in different premolt phases, which provided evidence for setal development in Callinectes exasperatus. Images A, C and $E$ show the dactile, and the scaphognathite is shown in images $B, D$ and $F$. Images $A$ and $B$ show the initial premolt phase; $C$ and $D$ show the advanced premolt phase; and images $E$ and $\mathrm{F}$ show the final premolt phase $(\mathrm{OC}=$ old cuticle; $d n c=$ development of the new cuticle; eb = enlarged bulb; er = epidermis retraction).

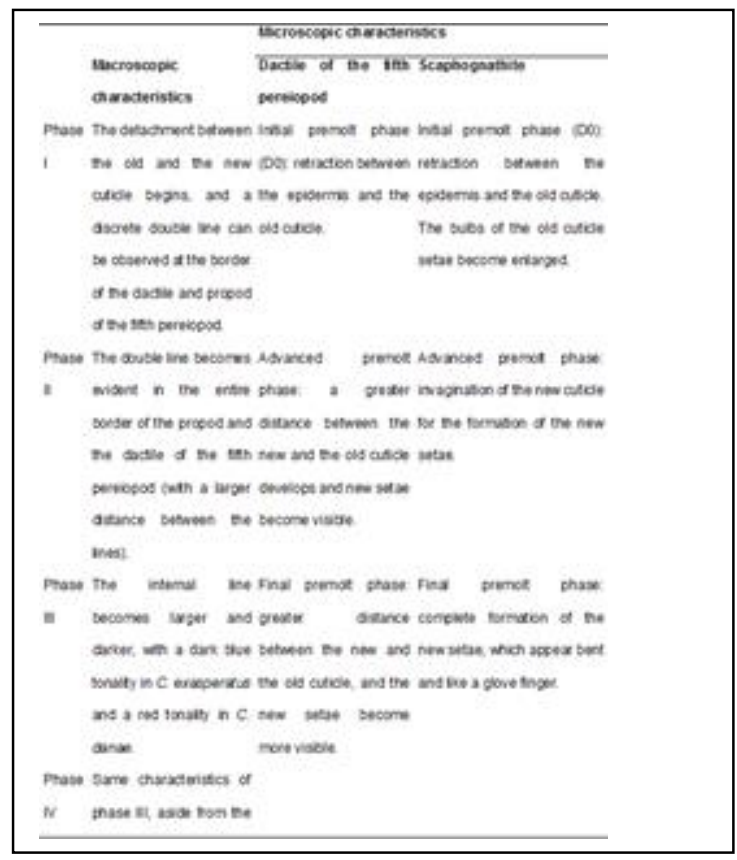

\section{Production of soft-shelled crabs}

In this assay, $25 \mathrm{C}$. danae and 16 C. exasperatus individuals survived (a survivorship rate of $62.5 \%$ and $40 \%$, respectively) until the end of the experiment. All of the deceased animals were part of the group that was initially characterized as being in premolt phase I. The remaining individuals of this group did not perform ecdysis and only one progressed to intermolt phase II.

All of the individuals that were initially characterized as being in premolt phase II or III survived, and eight of the individuals (four males and two females of $\mathrm{C}$. exasperatus, and two females of $\mathrm{C}$. danae) progressed to premolt phases II and III and underwent the molting process. Premolt phase IV was observed in only three of the individuals and the period between the observation of this phase and ecdysis was approximately eight hours. The estimated period between premolt phase II and ecdysis for two C. danae individuals was 3.33 and 5 days and ranged from 2.33 to 10.33 days for $\mathrm{C}$. exasperatus specimens, monitored in five individuals. The time lag between premolt phase I and ecdysis could not be 
measured because no individuals that were originally identified in this phase at the beginning of the assay molted.

Cannibalism was observed in all experimental units and resulted in a loss of appendages and in mortality. In five cases, despite the use of the net dome, shedders were eaten during or immediately after molting. The salinity ranged from 33 to $36 \mathrm{psu}$, the water temperature ranged from 27 to $29.8^{\circ} \mathrm{C}$, the dissolved oxygen varied between 3.55 and $3.8 \mathrm{mg} \cdot \mathrm{L}-1$, and total ammonium concentration remained under $0.12 \mathrm{mg} \cdot \mathrm{L}$ 1.

\section{DISCUSSION}

The macroscopic signs that were indicative of molt for $\mathrm{C}$. danae and $\mathrm{C}$. exasperatus were very similar to those that have been previously described for C. sapidus (Oesterling 1984) and C. arcuatus (Wehrtmann and MenaCastañeda 2003). Furthermore, it was possible to observe a differentiation in the color of the internal line between the two tested species in premolt phase III; in the borders of these segments, $C$. danae showed a red coloration and in $\mathrm{C}$. exasperatus, the regions were dark blue. The presence of a red line in the border of the propodus and dactylus of the fifth pereiopod was also described for $\mathrm{C}$. sapidus and C. arcuatus (Oesterling 1984, Wehrtmann and Mena-Castañeda 2003).

The microscopic analysis of setal development was consistent with the macroscopic signs. Additionally, the dactylus and scaphognathite of the fifth pereiopod allowed for the microscopic identification of the premolt sub-stages. The setal development process in the new tegument of scaphognathite appeared to be more evident in the advanced and final premolt phases, as opposed to the dactylus of the fifth pereiopod. Drach and Tchernigovtzeff management (1967) reported differences in setal development between the appendices of the same animal. The correlation between macro and microscopic signs observed in the present work indicates that macroscopic observations are a reliable tool to identify the molting phases and sufficient for selection of crabs about to molt for the evaluated species.

In the second assay, a high mortality rate and no observation of evolution into the intermolt phase of the individuals that were classified in premolt phase I indicated that the conditions were unsuitable for production of soft-shelled crabs. However, if we consider that all animals that were classified in premolt phases II and III survived and nearly all animals underwent ecdysis, it is possible to consider that this is a condition exclusively related to individuals in premolt phase I.

The environmental parameters that were used during this experiment were similar to the natural environments of the tested species (Melo 1996, Vinatea 2004, Cirano and Lessa 2007), with the exception of the concentration of dissolved oxygen. The dissolved oxygen concentrations in the second assay ranged from 3.55 to $3.8 \mathrm{mg} \cdot \mathrm{L}-1$, which is lower than recommended by Turano (year not informed) for the production of soft-shelled crabs. Oxygen is important for the molting process because during the premolt phase, the oxygen consumption of the crustacean is considerably increased (Skinner 1962). It is also possible that other factors, such as the high density of animals used and the absence of food, may have contributed to the low survivorship and molting rates that were observed for individuals in premolt phase I. However, the density of five individuals per tank (21 ind-m-2) used in our second experimental assay was lower than the density that is used for C. sapidus in soft-shelled crab production enterprises, which is approximately 35 ind $\cdot \mathrm{m}-2$ for individuals 
in premolt phase I (Maya de la Cruz et al. 2007), suggesting that perhaps the low survivorship is caused by the low dissolved oxygen concentration.

We opted not to provide food during the assay because we were following the methods adopted in softshelled crab production enterprises for the production of $\mathrm{C}$. sapidus (Wickins and Lee 2002, Maya de la Cruz et al. 2007). However, according to Warner (1977), crustaceans stop eating only when the animal reaches premolt stage D2 or late premolt; therefore, the no-food conditions may have impaired the molting process of premolt phase I individuals. The high survival and molting rate of premolt phase II and III individuals indicated that the individuals were able molt in captivity from premolt phase II on, even when they were not in an environment that was completely suitable for molting.

\section{CONCLUSIONS}

Our results show that is possible to identify when C. danae and C. exasperatus are about to molt by macroscopic observation of the propodus and dactylus of the fifth pereiopod and by observation of the disruption of the epimeral line. Furthermore, the results indicated that it is technically viable to increase production rates of soft-shelled crab for these species by selecting individuals in the premolt phases II, III and IV and maintaining them in specific facilities. In order to take advantage of this new process, further investigations are needed to identify the requisite conditions for successful molting of individuals in premolt phase I.

\section{Acknowledgements}

We thank the government of the state of Bahia and Bahia Pesca for funding this research and João B. L. Ghizoni for proofreading.

\section{REFERENCES}

BLUE CRAB TECHNICAL WORK GROUP. The Blue Crab 2005-Status of the Chesapeake Population and Its Fisheries. Maryland, Chesapeake Bay Commission Publication. 2005. Available:

http://www.chesbay.us/Publications/CBC-CRAB05.pdf, accessed: 02/13/2015.

CASTRO, L. A. B.; YAMANAKA, N.; ARFELLI, C. A; et al. Situação Atual da Cadeia Produtiva do Pescado no Litoral do Estado de São Paulo. Série Relatórios Técnicos, v. 21, p.1-55. 2005.

CIRANO, M.; LESSA, G.C. Oceanographic characteristics of Baía de Todos os Santos, Brazil. Revista Brasileira de Geofísica, v. 25, p. 363-387. 2007.

COELHO, P.A.; RAMOS-PORTO, M. Sinopse dos crustáceos decápodos brasileiros (Portunidae). Revista Brasileira de Zoologia, v. 9, n. 3/4, p. 291-298. 1992.

CUPKA, D. M.; VAN ENGEL, W.A. Proceedings of workshop on soft shell blue crabs, Charleston, South Carolina. Columbia, South Carolina Marine Resources Center. 1979. 99 p.

DRACH, P.; TCHERNIGOVTZEFF, C. Sur la méthode de détermination des stades d'intermue et son application générale aux Crustacés. Vie Milieu A Biologie Marine, v. 18, p. 595-607. 1967.

FOOD AND AGRICULTURE ORGANIZATION OF THE UNITED NATIONS. FAO Yearbook Fishery and Aquaculture Statistics. Rome, FAO. 2008. Available: http://www.fao.org/fi/website/MultiQueryResult.d o?loadMenu=PUBL_YearbooksofFisheryStatistic s\&xsl=webapps/figis/shared/xsl/multiquery.xsl\&q uery=http://www.fao.org/fi/eims_search/advance d_s_result.asp?owner $=$ fi $\% 26 \times \mathrm{xml}=\mathrm{y} \% 26 \mathrm{xml}$ no subject=y\%26FORM_C=AND\%26series $=215,37$ $7 \% 26$ tabs $=$ dc: $:$ ate $\% 26$ numrec $=100 \&$ lang $=$, accessed: 02/13/2015.

FREEMAN, J.A.; KILGUS, G.; LAURENDEAU, D.; et al. Postmolt and intermolt cycle stages of Callinectes sapidus. Aquaculture, v. 61 , p. 201209. 1987.

LEE, C. F.; SANFORD, F. B. Soft crab industry. Commercial Fisheries Review, v. 24, n. 1, p. 1012. 1962.

MAYA DE LA CRUZ, E.; CHAN-VADILLO, T.A.; GÓMEZ-MENDOZA, G.Y.; et al. Proceso Productivo de Jaiba Suave (Callinectes sapidus). Industria Acuícola, v. 3, n. 4, p. 16 -19. 2007. 
MELO, G.A.S. Manual de identificação dos Brachyura (caranguejos e siris) do litoral brasileiro. São Paulo, Editora Plêiade Fapesp. 1996.

MEYER, P. Blue crabs, catch' em, cook' em, eat' em. Wilmington, Avian Cetacean Press. 2003.

OESTERLING, J. Manual for handling and shedding blue crabs (Callinectes sapidus). Gloucester Point, Virginia Institute of Marine Science. 1984.

PERRY, H.M.; MALONE, R.F. Blue crabs: soft shell production. In: E.W. CAKE; WHICKER, L.F. E LANDNER C. M. (Eds.). Aquaculture profiles and opportunities in Mississippi. Mississippi, Mississippi Aquatic Ventures Center. pp. 1-32, 1989.

SKINNER, D.M. The structure and metabolism of a crustacean in tegumentary tissue during a molt cycle. The Biological Bulletin, v. 123, p. 635-647. 1962.

STEVENSON, J. R. Dynamics of the integument, p. 01-42. In: D.E. Bliss (Ed.). The Biology of Crustacea. New York, Academic Press inc. 1985.

VINATEA, A.L. Princípios químicos de qualidade da água em aquicultura. 2nd edn. Florianópolis, Editora UFSC. 2004.

WARNER, G.F. The Biology of Crabs. London, Van Nostrand Reinhold Company, 1977. 202 p.

WEHRTMANN, I.S.; MENA-CASTAÑEDA, D. Molt sign description of the Pacific blue crab Callinectes arcuatus Ordway 1863 (Decapoda, Portunidae). Nauplius, v. 11, n. 2, p. 135-139. 2003.

WICKINS, J.F.; LEE, D. O'C. Crustacean farming: ranching and culture. 2nd edn. Oxford, Blackwell Science. 2002. $464 \mathrm{p}$ 